Ege Eğitim Dergisi 2014 (15) 1: 211-232

\title{
Pedagojik Formasyon Öğrencilerinin Çok Kültürlü Eğitime Yönelik Tutumlarının Bazı Değişkenlere Göre İncelenmesi*
}

\author{
Ebru DEMIRCIOĞLU ${ }^{* *} \quad$ Murat ÖZDEMIR ${ }^{* * *}$
}

\section{$\ddot{O} \mathbf{z}$}

$\mathrm{Bu}$ araştırmada pedagojik formasyon öğrencilerinin çok kültürlü eğitime yönelik tutumları, çeşitli değişkenlere göre incelenmiştir. Araştırmaya Çankırı Karatekin Üniversitesi'nde 2012-2013 akademik y1lında pedagojik formasyon eğitimi alan 156 pedagojik formasyon öğrencisi katılmıştır. Tarama modelindeki araştırmada, Yavuz ve Anıl (2010) tarafından geliştirilmiş olan 'Öğretmen Adayları İçin Çok Kültürlü Eğitime Yönelik Tutum Ölçeği (ÖÇKET)' kullanılmıştır. Verilerin analizinde yüzde, frekans, aritmetik ortalama, standart sapma, $t$ testi ve Kruskall Wallis $H$ testi istatistik tekniklerinden yararlanılmıştır. Araştırmada, pedagojik formasyon öğrencilerinin çok kültürlü eğitime yönelik tutumlarının genel olarak ortalamanın üzerinde ve olumlu olduğu saptanmıştır. Cinsiyete göre yapılan analizlerde kadın öğrencilerin erkek öğrencilere göre çok kültürlü eğitime yönelik daha fazla olumlu tutuma sahip oldukları belirlenmiştir. Yaş ve mezun oldukları fakülte değişkenlerine göre ise katılımcıların çok kültürlü eğitime yönelik tutumlarının anlamlı bir farklılık göstermediği tespit edilmiştir. Bu bulgulara dayalı olarak, pedagojik formasyon öğrencilerinin çok kültürlü eğitime yönelik görece olumlu tutuma sahip oldukları genel sonucuna ulaşılmıştır.

Anahtar kelimeler: Çok kültürlülük, çok kültürlü eğitim, pedagojik formasyon öğrencileri.

\footnotetext{
* Bu çalışmanın bir bölümü Öğretmen Adaylarının Çok Kültürlü Eğitime Yönelik Tutumları Sempozyumu'nda (ISNITE'2013) sözlü bildiri olarak sunulmuştur.

** Arş. Gör., Çankırı Karatekin Üniversitesi, Edebiyat Fakültesi, 8706ebru@gmail.com

*** Doç. Dr., Hacettepe Üniversitesi, Eğitim Fakültesi, mrtozdem@gmail.com
} 


\title{
Analysis Of Pedagogical Formation Students' Attitudes Toward Multicultural Education
}

\begin{abstract}
In this research, pedagogical formation students' attitudes toward multicultural education were analyzed according to various variables. Totally 156 pedagogical formation students from Çankırı Karatekin University participated in the study. To gather data, 'The Attitude Scale toward Multicultural Education for Teacher Candidates-ASIMETC' was used. To analyze the data, various statistical techniques including percentage, frequency, arithmetical mean, standard deviation, $\mathrm{t}$ - test and Kruskall Wallis $\mathrm{H}$ test were used. Findings indicated that participants' attitudes toward multicultural education are relatively positive. It was also seen that participants' attitudes toward multicultural education did not differ according to ages and faculties. However, it was revealed that multicultural attitudes of the participants graduated from social sciences departments in the universities were significantly higher than the ones in sciences departments. The findings have also shown that the female participants have more positive attitudes toward multicultural education than the males. As a result, it was concluded that participants have positive attitudes toward multicultural education.
\end{abstract}

Key words: Multiculturalism, multicultural education, pedagogical formation students. 


\section{Giriş}

Son yıllarda Türk eğitim sisteminde köklü sayılabilecek reformların gerçekleştiği görülmektedir. Bu reformlar arasında en çok dikkati çekenler 2005-2006 eğitim-öğretim yılında uygulamaya geçen 'yapılandırmacı eğitim programları', Milli Eğitim Bakanlığının (MEB) 652 sayılı Kanun Hükmünde Kararname ile örgüt yapısının değiştirilmesi ve kamuoyunda $4+4+4$ olarak bilinen öğretim kademelerinin yeniden düzenlenmesidir. Bilginin hizla yenilenerek üretildiği, sınırların giderek birbirine yaklaştı̆̆l, yaşam standartlarının, aile yapısının, sosyal ve kültürel değerlerin değiştiği küreselleşen dünyada, eğitim programları yapılandırmacı yaklaşımı benimseyerek ayak uydurmaya çalışmaktadır. Pek çok ülkenin uzun süredir eğitim programlarında uyguladığı, Türkiye' nin ise 2005-2006 eğitim-öğretim döneminde geçiş yaptığı yapılandırmacı eğitim programı ile insan hakları, çok kültürlülük, çeşitlilik (dil, din, yaş, cinsel tercihler, etnik köken), kültürel duyarlılık, hızla kendini yenileyen teknolojik gelişmeler gibi faktörler gündeme gelmiştir (MEB, 2005). Bu süreçte insanların ve toplumların ihtiyaçları değişirken bilgi edinme, araştırma ve ölçme yöntemleri de hızlı bir değişimin içerisinde yer almaktadır.

Amerika'da öğretmen Eğitimi Ulusal Eşdeğerlik Komisyonu (National Council for Accrediation for Teacher Education) (NCATE), öğretmen adaylarının yetiştirilmesinde dikkate alınması gereken standartlardan birisini tüm öğrencilerin öğrenmelerine ve okullarda öğrenmelerini desteklemeye yardım edebilecek öğretmenleri yetiştirmek olduğunu belirtmiştir (Professional Standarts, 2008, Akt. Cırık, 2008). Bu amaç ise çok kültürlülüğg̈ ve farklı kültürlerden gelen öğrenciler ve ailelerin geçmişleri ve yaşanmışlıkları üzerinde duran küresel algıları yansıtabilen eğitimcileri gerektirmektedir. Cogan ve Pederson (2001), 21. yüzyılın öğretmeninin çok kültürlülük anlayışına ve yeterliliklerine sahip olması gerektiğini savunmaktadır. Ayrıca öğretmenin; ülkesi, ulusu ve tüm insanlıkla ilgili her türlü sosyal, ekonomik, kültürel, çevresel konulardan yurttaşlık haklarına kadar tüm sorunlara karşı duyarlı olması ve çözümünde aktif rol alması gerektiğini belirtmektedir. Üniversitelerde verilecek olan çok kültürlü eğitim dersleri saha deneyimleri ve klinik uygulamalarda eğitimde kültürün etkisini anlamak ve tüm öğrenciler için anlamlı öğrenme deneyimleri geliştirmelerine yardımcı olacak şekilde planlanmalıdır. Öğretmen adaylarının alacakları bu eğitim ile ırksal/etnik, kültürel, cinsiyet ve dil farklılıkları gibi faktörlerin öğrenme üzerindeki etkisi hakkında bilgi edinmeleri mümkün olabilecektir. Böylece ırk, sınıf, cinsiyet, öğrencilerin dilleri ve öğrenmelerine dayanan ayrımcıllğın potansiyel etkisini 
anlayabilirler ve eğitim-öğretim yaşantılarını bu faktörlere uygun olarak planlayabilirler (Professional Standarts, 2008).

Eğitim araştırmalarının son 20 yılı çok kültürlü eğitimin öneminin tanımlandığı çalışmaları içermektedir. Bu da son yıllarda çok kültürlü eğitim kavramının, bir eğitim sürecinde uygulanmasının ve değerlendirilmesinin bilim insanlarınca merak konusu olduğunu göstermektedir. Smith (1998), sadece öğretmen eğitimi programlarının içeriğinde değil tüm öğretim programlarında çok kültürlü eğitimin yer alması gerektiğini savunmaktadır. Ertürk (1998) kültürü, insanların birbirleriyle ve çevreleriyle etkileşimlerinin bir araya getirilerek örgütlenmiş ürünleri olarak tanımlamıştır. Çok kültürlülük, 1960'lı yıllarda ABD ve Avrupa'da toplumsal çeşitliliğin artması sonucunda insan hakları hareketlerinin gelişimine bağlı olarak ortaya çıkmıştır (Başbay ve Bektaş, 2009, s.30). ABD ve Avrupa Konseyi'ni İsveç, Avustralya, Bolivya ve Çin gibi çok kültürlü etnik dokuya sahip olan birçok ülke çok kültürlü eğitim reformunu hayata geçirerek takip etmiştir (Dahlin, 2010; Joseph ve Southcott, 2009; Minhui, 2011; Reid, 2011; Akt. Özdemir ve Dil, 2012). Okul öncesi sinıflardan başlayarak uygulamaya konulan çok kültürlü eğitim programlarının yanı sıra Amerika'daki bir "Öğretmen Eğitiminin Denkliğì" ile ilgili ulusal kurul, öğretmen hazırlama programlarına da çok kültürlü eğitim programının konulması gerektiğini belirtmiştir. $\mathrm{Bu}$ nedenle de bazı üniversiteler, öğrencilerinden lisans eğitimleri süresince çok kültürlü eğitimle ilgili en az bir ders almaların istemektedirler (Banks, 1993, Akt. Cırık, 2008).

Kültür; ortak güdülerin, değerlerin, inançların, kimliklerin ve toplum üyelerinin ortak deneyimleri sonucunda oluşan önemli olayların nesiller boyunca aktarılmasidır (House, Hanges, Javidan, Dorfman, ve Gupta, 2004, s. 15). Çok kültürlülük ise dil, din, ırk, cinsiyet, yaş, sosyal sınıf, etnik köken, engelli olma ve diğer kültürel değerlerin farkında olmaktır (APA, 2002). Çok kültürlülük kavramı düşünce dünyasındaki postmodernist etkinin uzantısı olan yapılandırmacı yaklaşımın güçlü yönlerini ve varsayımlarını destekleyen bir yaklaşım olarak doğmuştur (D'andrea, 2000; Highlen, 1996; Siviş, 2002). Çok kültürlülük olgusunun alt dallarından birisi olan çok kültürlü eğitim; farklı ırk, etnik yapı ve sosyal gruplardan gelen tüm öğrencilere eşit eğitim fırsatları yaratan, okul ortamını değiştirip yeniden yapılandıran bir eğitim yaklaşımıdır (Banks ve arkadaşları, 2001).

Parekh (2002), çok kültürlü eğitimi tanımlarken; entelektüel merak, özeleştiri, savları ve kanıtları değerlendirip bağımsız bir karar oluşturabilme, başkalarına sayg1, farklı düşünce ve yaşam biçimlerine duyarlı olma ve etnik merkezici bir anlayıştan uzaklaşma amacına yönelik yürütülen faaliyetlerden oluştuğunu vurgulamıştır (Akt. Başbay ve Bektaş, 2009). Gay (1994), alan yazında çok 
Pedagojik Formasyon Öğrencilerinin Çok Kültürlü Eğitime Yönelik Tutumlarının Bazı Değişkenlere

Göre İncelenmesi

kültürlü eğitimin 12 farklı anlamda kullanıldığını ve tanımlandığını belirtmektedir. Parekh'e (1986: 2627) göre en sık kullanılan çok kültürlü eğitim tanımlarından birisi; çocukların amaç ve yeteneklerinden esinlenerek, gelişen fikir ve deneyim farklılıklarının eğitim programlarını yönlendirmesidir. Bu da tüm öğrencilerin akademik başarıda eşit şansa sahip oldukları anlamına gelir. Bir diğer tanıma göre ise çok kültürlü eğitim, kültürel çeşitliliğe vurgu yapan bir felsefedir. Bu tanıma göre çok kültürlülük bireyi merkeze alır ve toplumu bir bütün içerisinde değerlendirir. 'Önyargıların olmadığı özgür bir eğitim, diğer alg1 ve kültürlerin açılamasında özgürce fikir ve deneyimlerin analiz edildiği farklı bir dünyada yaşamaktır' tanımı da günümüzde en çok ihtiyaç duyulan özelliklerden birisi olan özgür bir eğitimin altını çizer.

Gay (1994), çok kültürlü eğitimin temel amaçlarını eğitimde eşitlik ve başarı, değerleri ve tutumları açıklama, çok kültürlü sosyal yeterlilik, temel yetenek kazanımı, kültürel ve etnik okuryazarlığı geliştirmek ve kişisel gelişim olarak sıralamıştır. Çok kültürlü eğitimle ilgili özel amaçlar ve ilişkili hedefler oldukça çok sayıdadır ve okul kuralları, zamanlama, amaçlar ve görüşler gibi içeriksel faktörlerle uyumlu olarak çeşitlenirler. Çok kültürlü eğitim öz ve araçsal değerlerin (kişinin yaşam boyu ulaşmak istediği amaçları ve sergilediği davranışları) her ikisini birleştirir ve öğrenmenin hakimiyetinde bilişsel, duyuşsal ve psikomotor becerilerden oluşur. Bu amaç kümeleri etnik ve kültürel okur-yazarlık, kişisel gelişim, tutum ve değerler, çok kültürlü sosyal yetenekler, temel becerilerdeki uzmanlık, eğitim eşitliği ve üstünlüğü ve sosyal reformlardaki güçlendirmelerdir (Gay, 1994). Çok kültürlü eğitimin bu amaçlarına ulaşması için eğitim-öğretim sürecinde yer alan tüm eğitimcilerin ortak sorumluluk alması gerekmektedir. $\mathrm{Bu}$ nedenle eğitim-öğretim programları, okul rehberlik hizmetleri, okulun yönetilmesi ve eğitim-öğretim sürecinin değerlendirmesinde öncelikle çok kültürlü eğitime uygun bir okul ve sınıf ikliminin yaratılması gerekmektedir (Gay, 1994). Çok kültürlü eğitimin başarısı veya başarısızlığı öğretmenlerin ve yöneticilerin etkili hazırlanmalarına bağlıdır (Cochan-Smith, 2002).

Çok kültürlü eğitim, bilginin doğasına ilişkin kuram ve yaklaşımlar tarafından desteklenmektedir. Hidalgo ve arkadaşlarının (1996: 762) da belirttiği gibi 'çok kültürlü eğitim hareketinin özü sosyal yapılandırıcı kuramlara dayanır' (Akt. Yazıcı, Başol ve Toprak, 2009). Bu yönüyle yapılandırıcı yaklaşımla çok kültürlü eğitim arasında kavramsal ve mantıksal bir ilişkinin olduğu görülmektedir. Her iki yaklaşımın ortak özellikleri; bireysel farklılıkların önemli olması, her bireyin eşit davranış ve saygıyı hak etmesi ve bilginin sosyal ve kültürel çevrenin de dikkate alınması ile yapılandırılmasıdır. 
Öğretmenlerin çok kültürlü eğitime yönelik tutumlarını merkeze alan yurtdışı çalışmalar incelendiğinde özellikle 1997-2001 yılları arasında bu çalışmaların sayısında önemli bir artış olduğu görülmektedir. Grant ve Koskela (1986), üniversitede öğrenilen çok kültürlülük eğitimi ile öğretmenlerin okullarında uyguladıkları çok kültürlülük eğitimi arasındaki ilişkiyi incelemişlerdir. Araştırmanın sonucunda öğretmen adaylarının üniversitedeki sınıflarında çok kültürlü eğitim programı ile ilgili bilgi edindikleri ancak bu bilginin kapsamlı olmadığı ve genellikle birbirini tekrar eden konulardan oluştuğu görülmüştür. Aynı araştırmada üniversiteden mezun olan öğretmenlerin çalıştıkları okullarda, öğrendikleri çok kültürlü eğitim ile ilgili bilgileri uygulamayı denemedikleri sonucuna ulaşılmıştır.

Gasbarro ve Matthews (1994), çalışmalarında öğretmen eğitimi programlarında çok kültürlü eğitime yönelik yeni öğretmenlerin algıları ve çok kültürlülük terimine verdikleri anlamların daha iyi anlaşılmasını amaçlamışlardır. Gay (1995) ise program kuramı ve çok kültürlü eğitim arasındaki ilişkiyi incelemiştir. Eğitimde fırsat eşitliği ve mükemmelliğin, eğitim sürecinde kültürel çoğulculuk fikrinin tüm yönleriyle benimsenmeden elde edilemeyeceğini belirtmiştir. Ayrıca, eğitim programında gerçekleştirilen yenilikler ve çok kültürlü eğitimin unsurları arasındaki bağlantıların daha fazla araştırılmaya ihtiyacı olduğunu vurgulamıştır. Çalışmasının sonucunda ise öğretmenlerin, okullarda çalışmaya başlamadan önce çok kültürlü eğitim konusunda eğitim almalarının yararlı olacağı fikrine ulaşmıştır.

Spiecker ve Steutel'e (2001) göre, 21. yüzyıl öğretmeni çok kültürlülük, çoğulculuk ve liberal anlayışı benimsemelidir. Bir başka çalışmada da Neuharth-Pritchett, Reiff ve Pearson (2001), öğretmen adaylarının çok kültürlü eğitimle ilgili bilgi düzeylerini araştırmışlar ve öğretmen adaylarının çok kültürlü eğitim, ırk ve etnik köken ile ilgili bilgi ve anlayışlarının yetersiz olduğu sonucuna varmışlardır.

Yurt içinde yapılan çalışmalar incelendiğinde çok kültürlü eğitim çalışmalarının yeterli düzeyde olmadığı ve henüz gelişmekte olan bir kavram olduğu anlaşılmaktadır. Cırık (2008) çalışmasında, çok kültürlü eğitimin gelişim süreci ve öğrenme ortamlarına yansımalarını irdelemiştir. Başbay ve Bektaş (2009), çok kültürlülük bağlamında öğretim ortamı ve öğretmen yeterliklerini araştırmış ve çok kültürlülüğün, toplumsal yapıya zenginlik kattığı ve parçalanmayı değil bütünleşmeyi getirdiği düşüncesini ortaya koymuşlardır. Polat (2009), öğretmen adaylarının çok kültürlü eğitime yönelik kişilik özeliklerine ne kadar sahip olduklarını tespit etmiştir. Polat (2012), bir başka çalışmasında da okul müdürlerinin çok kültürlülüğe ilişkin tutumlarını incelemiş ve okul müdürlerine çok kültürlülük ile ilgili hizmet içi eğitim ve 
Pedagojik Formasyon Öğrencilerinin Çok Kültürlü Eğitime Yönelik Tutumlarının Bazı Değişkenlere

Göre İncelenmesi

duyarlılık eğitimi verilmesi gerektiğini belirtmiştir. 21. yüzyılda öğretmen yetiştirme eğitim programlarının boyutlarının araştırıldığı çalışmanın bulgularından birisi de öğretmenlerin kültürler arası eğitim ve demokratik bir toplum inşa etme anlayışında yetiştirilmeleridir.

Açıkalın (2010), çok kültürlü eğitimin çeşitli görünümlerini betimlediği bir derleme çalışması yapmıştır. Yazıcı, Başol ve Toprak (2009), Öğretmenlerin Çok Kültürlü Eğitim Tutum Ölçeği'nin uyarlama çalışmasını gerçekleştirmiş; Başbay ve Kağnıcı (2011) ise Çok Kültürlü Yeterlik Algıları Ölçeği'ni geliştirmişlerdir. Özdemir ve Dil (2012) öğretmenlerin çok kültürlü eğitim tutumlarının cinsiyete, medeni duruma, eğitim düzeyine, sendika üyeliğine ve kıdem değişkenlerine göre farklılık göstermediğini; eğitim fakültesi ve fen-edebiyat fakültesi mezunu olanların çok kültürlü eğitim tutumlarının, teknik eğitim fakültesinden mezun olan katılımcılara göre anlamlı şekilde yüksek olduğunu saptamışlardır. Demir (2012), çok kültürlü eğitimin Erciyes Üniversitesi öğretim elemanları için önem derecesini irdelemiştir. Demir ve Başarır (2013), öğretmen adaylarının, çok kültürlü eğitime ilişkin öz-yeterlik algılarını, cinsiyetlerine, ana dillerine, aile gelir düzeylerine, bölümlerine, anne ve baba eğitim durumuna, yerleşim yerlerine, nüfusa kayıtlı oldukları ilin bulunduğu coğrafi bölgeye göre farklılaşıp farklılaşmadığını araştırmıştır.

Belirtilen araştırmalar öğretmenler tarafından çok kültürlü eğitim kavramının anlaşılması ve eğitim-öğretim sürecinde uygulanması boyutunda eksikliklerin olduğunu göstermektedir. Alan yazında hissedilen bu eksikliğin giderilmesi amacıyla bu konuyla ilgili yapılan çalışmaların sayısı hızla artmaktadır. Çok kültürlü öğretim uygulaması öğretmenlerin çok boyutlu bakış açısına sahip olmalarını, farklı kültürlere hitap edecek materyaller ve yöntemler kullanmalarını (Grant ve Sleeter, 1998) ve öğrenme ortamlarını farklı kültürlerden gelen öğrencileri de göz önüne alarak düzenlemelerini gerektirir. $\mathrm{Bu}$ da öğretmenlerin çok kültürlü eğitime yönelik olumlu bir tutum sergilemeleri ile mümkündür. Araştırma bu açıdan önem taşımaktadır. Çünkü gerek yurtdışı gerekse yurtiçi alanyazın taramalarında, eğitim fakültesinden mezun olmayıp pedagojik formasyon eğitimi alan öğretmen adaylarının çok kültürlü eğitime yönelik tutumlarını, çeşitli değişkenler ile karşılaştırarak inceleyen araştırmaların çok az olduğu anlaşılmaktadır.

Türkiye'de pedagojik formasyon eğitimi; fen-edebiyat, güzel sanatlar, sağlık bilimleri, beden eğitimi ve spor yüksekokulu, dil-tarih-coğrafya ve ilahiyat fakültelerinden mezun olup Milli Eğitim Bakanlığı'nda öğretmen olarak çalışmak isteyen bireylerin alması gereken bir sertifika programıdır. Yüksek Öğretim Kurumu'nun 2010 yılında aldığı karar ile eğitim fakültesinden mezun 
olan öğrenciler ve fen-edebiyat fakültesi mezunu olup pedagojik formasyon eğitimini başarı ile tamamlayan öğrenciler, Milli Eğitim Bakanlığı tarafından yayınlanan Milli Eğitim Bakanlığı'na Bağlı Eğitim Kurumlarına Öğretmen Olarak Atanacakların Atamalarına Esas Olan Alanlar İle Mezun Oldukları Yüksek Öğretim Programları ve Aylık Karşılığı Okutacakları Derslere İlişkin Esasları sağladıkları takdirde öğretmenlik için başvuruda bulunabilmektedirler (YÖK, 2010).

Yapılan bu çalışmada da pedagojik formasyon eğitimi sertifika programına katılan öğretmen adaylarının çok kültürlü eğitime yönelik tutumları incelenmek istenmiştir. Çok kültürlü eğitim; var olan kalıplaşmış önyargılardan eğitimin sıyrılarak, demokratik bir eğitim anlayışına geçilmesinde köprü rolü üstlenir. Kısaca, çeşitli ırk, etnik köken, dil ve kültürel grupların, kadın ve erkek öğrencilerin okulda eşit akademik başarı şansına sahip olacakları şekilde eğitim kurumlarının yapısını değiştirmeyi amaçlayan bir reform hareketidir (Banks and Banks, 2009, s. 1). Bu gerekçelere dayalı olarak araştırmanın problemi, pedagojik formasyon eğitimi alan öğretmen adaylarının çok kültürlü eğitime yönelik tutumlarıdır. Bu çerçevede araştırmanın genel amacı, Çankırı Karatekin Üniversitesi'nde 2012-2013 eğitim-öğretim yllında pedagojik formasyon eğitimine devam eden öğrencilerin çok kültürlü eğitime yönelik tutumlarını saptamaktır. Bu genel amaç çerçevesinde aşağıdaki sorulara yanıt aranmıştır:

1) Pedagojik formasyon öğrencilerinin çok kültürlü eğitime yönelik tutumları nasıldır?

2) Pedagojik formasyon öğrencilerinin çok kültürlü eğitime yönelik tutumları cinsiyet, yaş, mezun oldukları fakülte, bölüm ve büyüyüp-yetiştikleri yere göre fark göstermekte midir?

\section{Yöntem}

Araştırma, tarama modelinin kullanıldığı, betimsel nitelikte bir çalışmadır. Karasar (1998: 77) betimsel nitelikli tarama modellerini, araştırmaya konu olan olay/olgu, birey ya da nesne, kendi koşulları içinde ve olduğu gibi tanımlanan bir yaklaşım olarak ifade etmektedir. Araştırma, nicel araştırma yaklaşımına göre desenlenmiştir.

\section{Çalışma Grubu}

Araştırma, Çankırı Karatekin Üniversitesi 2012-2013 eğitim-öğretim yılı güz döneminde verilmekte olan pedagojik formasyon eğitimine katılan 160 pedagojik formasyon öğrencisi üzerinde yürütülmüştür. Bu öğrenciler, farklı şehirlerden lisans not ortalaması ölçüt alınarak başarı puanlarına göre 
Pedagojik Formasyon Öğrencilerinin Çok Kültürlü Eğitime Yönelik Tutumlarının Bazı Değişkenlere

Göre İncelenmesi

pedagojik formasyon öğrenimi görmeye hak kazandıkları için çalışma örneklemi yöresel çeşitliliği yansıtmaktadır.

Katılımcıların 55'i erkek (\%34.4), 105'i kadın (\%65.6); 16'sı Güzel Sanatlar (\%10), 14 'ü Sağlık Bilimleri (\%8.8), 2'si Beden Eğitimi (\%1.3), 108'i Fen-Edebiyat (\%67.5), 2'si Dil-Tarih ve Coğrafya (\%1.3), 18'i İlahiyat (\%11.3) Fakültesinden mezundur. Katılımcıların üniversiteye giriş sınavındaki alan seçimleri göz önünde bulundurularak, lisans programları sözel ve sayısal olmak üzere iki gruba ayrılmıştır. 111 öğrenci sözel (resim, grafik, antrenörlük, çocuk gelişimi, İngiliz dili ve edebiyatı, tarih, sanat tarihi, felsefe, coğrafya, sosyoloji, edebiyat, çağdaş Türkçe, din kültürü ve spor) (\%69.4), 49 öğrenci sayısal (hemşirelik, matematik, fizik, kimya, biyoloji ve hemşirelik) (\%30.6) alanda öğrenim görmüştür. Görüldüğü üzere katılımcıların çoğu kadın, fen-edebiyat fakültesi ve sözel bir alandan mezun olan kişilerden oluşmaktadır.

\section{Veri Toplama Aracı}

Bu çalışmada Yavuz ve Anıl (2010) tarafından geliştirilmiş olan 'Öğretmen Adayları İçin Çok Kültürlü Eğitime Yönelik Tutum Ölçeği (ÖÇKET)' veri toplama aracı olarak kullanılmıştır. Ölçek, 22'si olumlu ve 6'sı olumsuz olmak üzere toplam 28 maddeden oluşan beşli likert tipindedir. Seçeneklerin; 'Tamamen Katılıyorum', 'Katıllyorum', 'Kısmen Katılıyorum', 'Katılmıyorum' ve 'Hiç Katılmıyorum' biçiminde sıralandığı ölçeğin maddeleri olumlu ve olumsuz oldukları göz önüne alınarak puanlandırılmıştır. Ölçekte yer alan maddelerden 1. madde olan "Öğretmen adayları, farklı kültürleri analiz edip değerlendirebilecekleri bir eğitim sürecinden geçmelidir." olumlu bir tutuma, 4 . madde olan "Farklı kültürlere yönelik eğitim faaliyetleri toplumsal birliği bozar." olumsuz bir tutuma örnek olarak verilebilir. Ölçeğin güvenirlik ve geçerlik çalışmaları Yavuz ve Anıl (2010) tarafından 214 katılımcı görüşlerine dayalı olarak yapılmıştır. Sözü edilen çalışmada ÖÇKET'in Cronbach's Alpha güvenirlik değeri 0.93 olarak hesaplanmıştır. Ölçeğin yapı geçerliği açımlayıcı faktör analizi ile test edilmiş ve tek boyutlu bir yapıyı ölçtüğü tespit edilmiştir.

$\mathrm{Bu}$ araştırma kapsamında ölçeğin uygunluğuna ilişkin geçerlik ve güvenirlik çalışmaları yinelenmiştir. 160 katılımcının ölçeğe verdikleri cevaplardan elde edilen puanlara, faktör analizi uygulanmadan önce verilerin çok değişkenli analiz varsayımlarını karşılayıp karşılamadığı tespit edilmiştir. Bu nedenle veriler üzerinde örneklem büyüklüğü, kayıp değer, normallik, uç değerler, doğrusallık, çoklu bağlantı ve tekillik testleri yapılmıştır. Çok yönlü uç değere sahip olması nedeniyle 17. ve 44 . birey veri setinden çıkarılmıştır. Ayrıca örneklemde Beden Eğitimi ve Spor Yüksekokulu bölümünden 2 kişinin olması, 
yapılacak istatistikler analizlerde sağlıklı sonuçlar üretmeyeceği gerekçesiyle analiz dışında bırakılmıştır. Bu durumda 156 veri üzerinden analizler yapılmaya devam edilmiştir. Verilerin faktör analizine uygun olduğunun görülmesinin ardından veriler açımlayıcı faktör analizine tabi tutularak temel faktörler belirlenmiştir. Ölçeğin KMO değeri 0.81 bulunmuş ve Bartlett Testi anlamlı $(p=0.00)$ çıkmıştır. Ölçek orjinaline uygun olarak tek boyutla sınırlandırılmış ve faktör yapısını belirlemek amacıyla, faktör analizi yöntemlerinden döndürülmemiş ve asal eksenlere göre döndürülmüş (varimax rotated) temel bileşenler analizinden yararlanılmıştır. 2. ve 25. maddeler binişik olmaları nedeniyle ölçekten çıkarılmış ve ölçek maddelerinin faktör yükleri 0.30 ile 0.67 arasında değer almıştır. Böylece ölçeğin bu araştırmada da tek faktörlü olarak kullanılabileceği sonucuna ulaşılmıştır. Her bir maddenin ayırt ediciliğini belirlemek için madde test korelasyonları hesaplanmış ve madde ayırt edicilik değerlerinin 0.27 ile 0.58 arasında değiştiği görülmüştür. Ölçeğin güvenirliğini belirlemek için hesaplanan Cronbach's Alfa katsayısı ise 0.77 olarak hesaplanmıştır. ÖÇKET'nin mevcut araştırma kapsamında kullanılabilecek geçerli ve güvenilir bir veri toplama aracı olduğu sonucuna ulaşılmıştır.

\section{Verilerin Analizi}

Katılımcılardan toplanan veriler aritmetik ortalama, standart sapma, yüzde ve varyans analizi istatistik teknikleri kullanılarak çözümlenmiştir. Pedagojik formasyon öğrencilerinin çok kültürlü eğitime yönelik görüşlerinin cinsiyete göre anlamlı farklılık gösterip göstermediğini belirlemek için $t$ testinden; yaş, mezun oldukları fakülte, bölüm ve büyüyüp-yetiştikleri yere göre farklılık gösterip göstermediğini belirlemek için de normal dağılım özelliği taşımayan 30'dan küçük sayıdaki gruplar için kullanılan bir analiz olan Kruskal Wallis H testinden yararlanılmıştır. Aritmetik ortalamalar yorumlanırken aralıklar 1.001.79, oldukça düşük; 1.80-2.59, düşük; 2.60-3.39, orta; 3.40-4.19 yüksek; 4.20-5.00 aralığı ise, oldukça yüksek olarak değerlendirilmiştir. Düzeylerin yer aldığı bu aralıklar, ölçek maddelerine verilen en düşük " 1 " ile en yüksek " 5 " puanlarının arasındaki seri genişliğinin seçenek sayısına bölünmesi ile elde edilmiştir. Verilerin istatistiksel analizleri için SPSS 20 programı kullanılmış ve hata payı üst sınırı 0.05 olarak kabul edilmiştir.

\section{İşlemler}

Pedagojik formasyon öğrencilerine araştırmanın amacı ile ilgili bilgi verildikten sonra, demografik bilgilerini öğrenebilmek için hazırlanan "Ön Bilgi Formu'nun" eklenmesiyle son şekli verilen ölçme aracı, 2012-2013 eğitim- 
Pedagojik Formasyon Öğrencilerinin Çok Kültürlü Eğitime Yönelik Tutumlarının Bazı Değişkenlere Göre İncelenmesi

öğretim yılı güz döneminde öğrenim gören öğrencilere araştırmacılar tarafından uygulanmıştır. Uygulama süresi 5-10 dakika arasında değişmektedir. Verilerin toplanması sırasında araştırma etiğine uygun davranılarak gönüllülük ilkesine uyulmuş ve araştırmaya katılmak istemeyen öğrencilere ölçme aracı dağıtılmamıştır.

\section{Bulgular}

Bu bölümde, araştırmada ele alınan problemin çözümü için toplanan verilerin istatistiksel çözümlenmesi sonucunda elde edilen bulgulara ilişkin ulaşılan sonuçlara yer verilmiştir.

1) Pedagojik formasyon öğrencilerinin çok kültürlü eğitime yönelik tutumları nasıldır?

Pedagojik formasyon öğrencilerinin çok kültürlü eğitime yönelik tutumları cinsiyet, yaş, mezun oldukları fakülte, bölüm ve yetiştikleri yer değişkenleri bakımından incelenmiş ve bulgular Tablo 1'de sunulmuştur.

Tablo 1. Pedagojik Formasyon Öğrencilerinin Demografik Özelliklerine Göre Dağılımları ve Çok Kültürlü Eğitim Puan Ortalamaları (N=156)

\begin{tabular}{|c|c|c|c|c|c|}
\hline Değişkenler & Gruplar & $f$ & $\%$ & $\bar{X}$ & Ss \\
\hline \multirow[t]{2}{*}{ Cinsiyet } & Kadin & 103 & 66.02 & 4.06 & 0.32 \\
\hline & Erkek & 53 & 33.98 & 3.94 & 0.42 \\
\hline \multirow[t]{3}{*}{ Yaş } & $20-25$ & 94 & 60.25 & 4.00 & 0.37 \\
\hline & $26-30$ & 35 & 22.43 & 4.06 & 0.37 \\
\hline & 31 ve + & 27 & 17.32 & 4.03 & 0.37 \\
\hline \multirow[t]{4}{*}{ Fakülte } & $\begin{array}{l}\text { Güzel } \\
\text { Sanatlar }\end{array}$ & 15 & 9.61 & 3.99 & 0.40 \\
\hline & $\begin{array}{l}\text { Sağllk } \\
\text { Bilimleri }\end{array}$ & 14 & 8.97 & 3.97 & 0.38 \\
\hline & Fen-Edebiyat & 109 & 69.87 & 4.04 & 0.36 \\
\hline & İlahiyat & 18 & 11.55 & 3.98 & 0.37 \\
\hline \multirow[t]{2}{*}{ Alan } & Sayısal & 6 & 3.85 & 3.72 & 0.43 \\
\hline & Sözel & 150 & 96.15 & 4.03 & 0.36 \\
\hline \multirow[t]{3}{*}{ Yerleşim Yeri } & Köy & 15 & 9.62 & 4.13 & 0.35 \\
\hline & Kasaba & 13 & 8.33 & 4.03 & 0.30 \\
\hline & Kent & 128 & 82.05 & 4.01 & 0.37 \\
\hline TOPLAM & Tüm Gruplar & 156 & 100 & 4.02 & 0.36 \\
\hline
\end{tabular}


Tablo 1'e göre pedagojik formasyon öğrencilerinin ( $N=156)$ çok kültürlü eğitime yönelik tutumlarının puan ortalaması 4.02'dir. $\mathrm{Bu}$ bulgudan katılımcıların çok kültürlü eğitime yönelik tutumlarının olumlu yönde ve ortalamadan yüksek düzeyde olduğu söylenebilir. Cinsiyet, yaş, fakülte, bölüm ve büyüyüp-yetiştiği yer bağımsız değişkenleri ayrı ayrı incelendiğinde olumlu yönde oldukları ve ortalamanın üzerinde değer aldıkları görülmektedir.

2) Pedagojik formasyon öğrencilerinin çok kültürlü eğitime yönelik tutumları cinsiyet, yaş, mezun oldukları fakülte, bölüm ve büyüyüpyetiştikleri yere göre fark göstermekte midir?

Pedagojik formasyon öğrencilerinin cinsiyetlerine göre, çok kültürlü eğitime yönelik tutumlarının karşılaştırılmasına ilişkin bağımsız örneklemler için $t$ testi sonuçları Tablo 2' de sunulmuştur.

Tablo 2. Pedagojik Formasyon Öğrencilerinin Çok Kültürlü Eğitime Yönelik Tutumlarının Cinsiyet Değişkenine Göre Karşılaştırılması (N=156)

\begin{tabular}{llllllll}
\hline Değişskenler & $\begin{array}{l}\text { Alt- } \\
\text { Gruplar }\end{array}$ & $\mathbf{N}$ & $\bar{X}$ & Ss & Sd & t & $\mathbf{p}^{*}$ \\
Cinsiyet & Kadın & 103 & 4.06 & 0.32 & 154 & -2.021 & 0.04 \\
& Erkek & 53 & 3.94 & 0.42 & & & \\
\hline
\end{tabular}

${ }^{*} \mathrm{p}<0.05$

Tablo 2'de yer alan $\mathrm{t}$ testi sonuçları incelendiğinde, pedagojik formasyon öğrencilerinin çok kültürlü eğitime yönelik tutum puanlarının cinsiyete göre anlamlı bir farklılık gösterdiği görülmektedir [t(156) $=-2.02 ; \mathrm{p}<0.05]$. Kadın öğrenciler $(\bar{X}=4.06)$ erkek öğrencilere $(\bar{X}=3.94)$ göre çok kültürlü eğitime yönelik tutum hakkında daha olumlu bir görüşe sahiptir.

Pedagojik formasyon öğrencilerinin çok kültürlü eğitim tutum puan ortalamalarının yaş, mezun olunan fakülte, bölüm ve yetişilen yer alt gruplarına göre karşılaştırılmasına ilişkin Kruskal Wallis $\mathrm{H}$ testi sonuçları Tablo 3'de sunulmuştur. 
Pedagojik Formasyon Öğrencilerinin Çok Kültürlü Eğitime Yönelik Tutumlarının Bazı Değişkenlere Göre İncelenmesi

Tablo 3. Pedagojik Formasyon Öğrencilerinin Çok Kültürlü Eğitime Yönelik Tutumlarının Yaş, Mezun Olunan Fakülte, Bölüm ve Yetişilen Yer Değişkenlerine Göre Karşılaştırılması $(N=156)$

\begin{tabular}{|c|c|c|c|c|c|c|c|}
\hline \multirow[b]{2}{*}{ Değişkenler } & \multirow[b]{2}{*}{ Alt-Gruplar } & \multirow[b]{2}{*}{$\mathbf{N}$} & \multirow[b]{2}{*}{$\begin{array}{l}\text { Siralar } \\
\text { Ortalamasi }\end{array}$} & \multirow[b]{2}{*}{ Ss } & \multirow[b]{2}{*}{ Sd } & \multicolumn{2}{|c|}{ Kruskal Wallis $\mathrm{H}$} \\
\hline & & & & & & $X^{2}$ & $\mathbf{P}$ \\
\hline \multirow[t]{3}{*}{ Yaş } & $20-25$ & 94 & 76.45 & 0.37 & 2 & 0.67 & $0.71^{*}$ \\
\hline & $26-30$ & 35 & 83.76 & 0.37 & & & \\
\hline & $31 \mathrm{ve}+$ & 27 & 78.83 & 0.32 & & & \\
\hline \multirow[t]{4}{*}{ Fakülte } & Güzel Sanatlar & 15 & 75.50 & 0.40 & 3 & 1.23 & $0.74^{*}$ \\
\hline & Sağlık Bilimleri & 14 & 70.96 & 0.38 & & & \\
\hline & Beden Eğitimi & 109 & 81.04 & 0.36 & & & \\
\hline & Fen-Edebiyat & 18 & 71.50 & 0.37 & & & \\
\hline \multirow[t]{2}{*}{ Bölüm } & Sözel & 150 & 79.82 & 0.36 & 1 & 3.31 & $0.04^{* *}$ \\
\hline & Sayısal & 6 & 45.58 & 0.43 & & & \\
\hline Yerleşim & Köy & 15 & 94.40 & 0.35 & 2 & 2.30 & $0.31^{*}$ \\
\hline \multirow[t]{2}{*}{ Yeri } & Kasaba & 13 & 70.85 & 0.30 & & & \\
\hline & Kent & 128 & 77.41 & 0.37 & & & \\
\hline
\end{tabular}

Tablo 3'de yer alan pedagojik formasyon öğrencilerinin çok kültürlü eğitime yönelik tutumlarının yaş, mezun olunan fakülte, bölüm ve büyüyüp-yetiştikleri yer değişkenlerine göre karşılaştırılmasına ilişkin Kruskal Wallis $\mathrm{H}$ testi sonuçları incelendiğinde; yaş $\left[\mathrm{KWH}_{(3)}=0.67 ; \mathrm{p}>0.05\right]$, mezun olunan fakülte $\left[\mathrm{KWH}_{(5)}=1.23 ; \mathrm{p}>0.05\right]$ ve yetiştikleri yere $\left[\mathrm{KWH}_{(2)}=2.30 ; \mathrm{p}>0.05\right]$ göre farkların anlamlı olmadığı görülmektedir. Pedagojik formasyon öğrencilerinin çok kültürlü eğitime yönelik tutumları mezun olunan bölüme göre ise anlamlı şekilde farklılık göstermektedir $\left[\mathrm{KWH}_{(1)}=3.31 ; \mathrm{p}<0.05\right]$. Bu farkın hangi bölüm tarafından daha yüksek olduğunun belirlenmesi amacıyla çoklu (Post Hoc) karşılaştırma yapılması gerekir. Ancak bölüm değişkeni iki gruplu bir değişken olması nedeniyle çoklu karşılaştırma yapılamamıştır. Sözel bölümden $(\bar{X}=79.82)$ mezun olan pedagojik formasyon öğrencilerinin sayısal bölümden $(\bar{X}=45.58)$ mezun olan pedagojik formasyon öğrencilerine göre çok kültürlü eğitime yönelik tutumlarının daha olumlu olduğu saptanmıştır. Buna göre çok kültürlü eğitim ile ilgili pedagojik formasyon öğrencileri arasından sözel bölüm 
mezunlarının sayısal bölüm mezunlarına göre daha olumlu bir tutuma sahip olduklarından bahsedilebilir.

\section{Tartışma}

$\mathrm{Bu}$ araştırmada pedagojik formasyon öğrencilerinin çok kültürlü eğitime yönelik tutumlarının cinsiyet, yaş, mezun olunan fakülte, bölüm ve büyüyüpyetişilen yere göre değişip değişmediği 156 katılımcıdan toplanan veriler üzerinden test edilmiştir. Çok kültürlülük, farklı kültürlere sahip bireylerin bir araya gelerek oluşturdukları bir yapıdır. Farklı kültürler; ırk, etnik köken, sınıf, dil, din, yaş, yaşanan yer, sosyal, eğitim ve ekonomik statü gibi geniş bir perspektifte düşünülebilir (Başbay ve Bektaş, 2009; Peterson, 1991; Valentiin, 2006). Çok kültürlü eğitim ise bu geniş perspektifte öğrencilerin tüm sorunlarına karşı duyarlı, çözüm üretme sürecinde aktif ve demokratik bir eğitim anlayışını benimseyen öğretmenler ile gerçekleştirilebilir. Bu kapsamda gerçekleştirilen çalışmanın bulguları, pedagojik formasyon öğrencilerinin çok kültürlü eğitime yönelik tutumlarının genel olarak ortalamanın üzerinde ve olumlu yönde olduğunu göstermektedir. Bu bulgu Polat'ın (2012), okul müdürlerinin çok kültürlülüğe ilişkin tutumlarını araştırdığı çalışmasında saptadığı okul müdürlerinin çok kültürlülüğe ilişkin olumlu tutuma sahip oldukları bulgusunu desteklemektedir. Benzer şekilde Hasırcı ve Gözük (2012), sınıf öğretmenlerinin çok kültürlülük tutumları ile düşünme stillerini araştırdıkları çalışmalarında, sınıf öğretmenlerinin çok kültürlülüğe karşı olumlu tutum sergiledikleri bulgusuna ulaşmışlardır. Yine Erciyes Üniversitesi öğretim üyeleri ile yapılan bir başka çalışmada da öğretim üyelerinin çok kültürlü eğitimi önemsedikleri sonucuna ulaşılmıştır (Demir, 2012). Ayrıca Capella-Santana (2003), öğretmen adaylarının çok kültürlü tutum ve bilgileri üzerindeki pozitif değişimlerle ilgili sözleri başlıklı araştırmasında öğretmen adaylarının çok kültürlü tutum ve bilgilerinin adayların bir öğretmen hazırlık programına katıldıklarında pozitif yönde değiştiği sonucuna ulaşmıştır. Adaylardaki değişimde kültürel/etnik çeşitlilik, çok kültürlü ve iki dilli eğitim ve öğrencilerden edinilen saha deneyiminin etkisinin olduğu görülmüştür. Ancak, Neuharth-Pritchett, Reiff ve Pearson (2001) öğretmen adaylarının çok kültürlü eğitimi nasıl tanımladıklarını araştırdığı çalışmasında öğrencilerin tanımlarının çoğunlukla ırk ve etnikle sınırlı kaldığı, çok kültürlü eğitimi en düşük düzeyde anladıkları ve kavramsallaştırdıkları şeklinde farklı bir sonuç bulmuştur. Ayrıca katılımcıların büyük çoğunluğu üniversitelerin çok kültürlülük ile ilgili öğrenci tutumları üzerinde büyük bir etkiye sahip olabileceği konusunda hemfikirdirler.

Araştırmaya katılan pedagojik formasyon öğrencilerinin çok kültürlü eğitime yönelik tutumları cinsiyet ve mezun olunan bölüme göre incelendiğinde aralarında anlamlı farklar olduğu gözlenmiştir. Bu durum erkeklerin ve 
Pedagojik Formasyon Öğrencilerinin Çok Kültürlü Eğitime Yönelik Tutumlarının Bazı Değişkenlere

Göre İncelenmesi

kadınların çok kültürlü eğitime farklı açıdan baktıklarının ve aralarında bir ayrım olduğunun göstergesidir. Bu ayrımın bir benzeri Keller'in (2001), matematiğin erkek işi olduğuna yönelik kalıp yargıların oluşumunda öğretmenlerin etkisi konulu çalışmasında da görülmüştür. Bu çalışmaya göre, matematik erkek işi olarak görülmektedir ve bu tarz yargılar öğrencilerin kişisel yeteneklerinin önemsenmediğinin bir göstergesidir. Bu bulgu Özdemir ve Dil'in (2012) saptadığı öğretmenlerin çok kültürlü eğitim tutumlarının cinsiyet, medeni durum, eğitim düzeyi, sendika üyeliği ve kıdeme göre farklılık göstermediği sonucu ile benzer; eğitim fakültesi ve fen-edebiyat fakültesi mezunlarının çok kültürlü eğitim tutumlarının, teknik eğitim fakültesinden mezun olanlara göre anlamlı şekilde yüksek olduğu sonucundan ise farklıdır.

Diğer yandan sonuçlara göre yaş, mezun olunan fakülte ve büyüyüp-yetişilen yer değişkenlerine göre katılımcıların çok kültürlülüğe bakış açıları incelendiğinde çok kültürlü eğitime yönelik öğretmen tutumlarında farklılaşma olmadığ1 bulunmuştur. Bu bulgu Yazıcı, Başol ve Toprak'ın (2009) öğretmenlerin cinsiyet değişkenine göre çok kültürlü eğitime yönelik öğretmen tutumlarında farklılaşma olmadığı, öğretmenlerin mezun oldukları fakülte, mesleki kıdem, çalıştıkları ilköğretim kademeleri ve çalıştıkları okulun il ya da ilçede olmasına göre çok kültürlülük eğitimine bakışlarında farklılık olduğu bulgusunu desteklememektedir. Demir ve Başarır (2013), yerleşim yeri değişkeninin çok kültürlülüğe bakış açısına etkisini incelemişler ve eğitim fakültesinde öğrenim gören öğretmen adaylarının çok kültürlü yeterlik algılarının yerleşim yerine göre değiştiğini saptamışlardır. Özellikle de büyükşehirlerden gelen adayların kendilerini çok kültürlü eğitim açısından daha yeterli buldukları görülmüştür. Çelik (2011), sosyal bilgiler öğretmenliği bölümünde okuyan öğretmen adayları ile yaptığı çalışmasında Medya okuryazarlığı dersinin öğretmen niteliklerinden çok kültürlü tutum geliştirmelerine etkisini incelemiştir. Yapmış olduğu deneysel çalışmasında, kontrol grubunun öntest ve sontest puanları arasında anlamlı bir fark bulunmadığı; deney grubunun öntest sontest puanları arasında anlamlı bir fark bulunduğu sonucuna ulaşmıştır. Ancak bu fark medya okuryazarlığı dersinin çok kültürlü tutum geliştirmelerine yönelik olumlu yönde bir fark değildir.

Önceki araştırma ile mevcut araştırma bulguları değerlendirildiğinde, pedagojik formasyon öğrencilerinin çok kültürlü eğitime karşı olumlu tutum sergiledikleri sonucuna ulaşılmıştır. Bu da öğrencilerin çok kültürlü eğitimi kabul ettikleri ve önemsedikleri şeklinde yorumlanabilir. Çok kültürlü eğitime yönelik tutumun olumlu olmasının nedenleri arasında öğrencilerin daha önce çeşitlilik içeren bir öğretim ortamında bulunmaları ve kültürel çeşitliliğe karşı kendilerini hazır hissetmeleri olabilir. Bu öğrenme ortamları; farklı kültürel 
değerlerle ilgili panel, açı oturum veya münazaralar ya da farklı kültürlerden gelen bireylerle kurulan işbirliği sürecinde ortak bir ürün ortaya çıkarma süreci olabilir. Sheets ve Chew (2000), Chan (2002), McNeal, (2005) ve Cırık (2008) çok kültürlü eğitimin, eğitim-öğretim ortamlarında yer almasının eğitimden alınan kaliteyi büyük ölçüde artıracağını düşünmektedir. İlköğretim ve ortaöğretimde çok kültürlü eğitim konusunda başarıya ulaşmak için çok kültürlü öğretme ve öğrenme, öğretmen eğitiminden itibaren etkili bir şekilde gerçekleşmelidir (Ngai, 2004). Bunun için nitelikli öğretmenler yetiştirilmelidir. MEB (2008), öğretmenlerin sahip olması gereken nitelikleri altı temel yeterlik alanı başlığı altında toplamıştır: (1) kişisel ve mesleki değerler, (2) öğrenciyi tanıma, (3) öğretme-öğrenme süreci, (4) öğrenmeyi, gelişimi izleme ve değerlendirme, (5) okul, aile ve toplum ilişkileri ve (6) program ve içerik bilgisidir. Öğretmen nitelikleri; uluslara, bireylere ve inançlara karşı ayrımcılık yapmamayı, sınıf içi ve dışı etkinliklerde demokratik davranmayı ve daha birçok kişisel ve mesleki olgunluk özelliklerini barındırmayı gerektiren çok kültürlü tutumlar gerektirmektedir (MEB, 2012).

\section{Sonuç ve Öneriler}

Fen-Edebiyat, güzel sanatlar, sağllk bilimleri, beden eğitimi ve spor yüksekokulu, dil-tarih coğrafya ve ilahiyat bilimleri fakültelerinin temel işlevi her bir alana yönelik bilimsel çalışmalar üretmek, bilim adamı ve araştırmacılar yetiştirmektir. Eğitim fakültelerinin temel işlevi ise öğretmen yetiştirmektir. Ancak ülkemizde yapılan bir uygulama ile fen-edebiyat, güzel sanatlar, sağlık bilimleri, beden eğitimi ve spor yüksekokulu, dil-tarih coğrafya ve ilahiyat bilimleri fakültelerinden mezun kişilere pedagojik formasyon sertifikası verilerek eğitim fakültesinden mezun olan kişilerle eş değer tutulmaktadırlar. Bu konuda hem eğitim fakülteleri hem de diğer fakültelerin belirttiği çeşitli eleştiriler bulunmaktadır. YÖK 27.08.2009 tarihinde üniversitelerden gelen talepler doğrultusunda 2009-2010 öğretim yılında fen-edebiyat ve MEB'in istihdam ettiği alanlarda mezun veren diğer alanlardaki öğrencilerin pedagojik formasyon eğitimi almalarına karar vermiştir (YÖK, 2009). 2009 yllından itibaren belirli aralıklarla uygulanan pedagojik formasyon eğitimi alarak öğretmen olmayı amaçlayan adaylar üzerinde yapılan bu çalışmada ise öğretmen olmak isteyen pedagojik formasyon öğrencilerinin çok kültürlü eğitime yönelik tutumlarının hangi düzey ve yönde olduğunun belirlenmesine yönelik üç temel sonuca ulaşılmıştır. Bunlardan birincisi pedagojik formasyon öğrencilerinin çok kültürlü eğitime yönelik tutumlarının genel olarak ortalamanın üzerinde ve olumlu yönde olduğudur. İkincisi araştırmaya katılan pedagojik formasyon öğrencilerinin çok kültürlü eğitime yönelik tutumlarının cinsiyet ve mezun olunan bölüme göre aralarında anlamlı farklar olmasıdır. Üçüncüsü ise yaş, mezun olunan fakülte ve büyüyüp-yetişilen yer 
Pedagojik Formasyon Öğrencilerinin Çok Kültürlü Eğitime Yönelik Tutumlarının Bazı Değişkenlere

Göre İncelenmesi

değişkenlerine göre katılımcıların çok kültürlülüğge bakış açlları incelendiğinde çok kültürlü eğitime yönelik öğretmen tutumlarında farklılaşma olmamasıdır.

Gelişen bilim ve teknoloji ile ihtiyaç duyulan öğretmen niteliği ve yeterliği de değişmiştir. Bu nedenle üniversitelerde çok kültürlü eğitimin temele alındığ1 hızlı bir müfredat dönüşümünün yapılması gerektiği düşünülmektedir. Bu açıdan çok kültürlü eğitimin öneminin Türkiye'de fark edildiği ve gelecekte daha iyi anlaşılacağı düşünülerek sonraki çalışmaların daha geniş bir katılımcı kitlesi ve eğitim kademelerinde yapılması önerilebilir. Bununla birlikte pedagojik formasyon öğrencilerinin çok kültürlülüğe yönelik farkındalıklarını artıracak uygulamaların yapılabileceği deneysel çalışmalar da gerçekleştirilebilir. Erkek pedagojik formasyon öğrencilerinin kadın pedagojik formasyon öğrencilerine göre çok kültürlü eğitime yönelik tutumlarının daha düşük olmasına neden olan faktörler araştırılabilir. İlköğretimin ilk kademesinden üniversite eğitimine kadar uzanan formal eğitim sürecinde öğrencilere farklılıkları tanıma ve kabul etme, birbirini dinleme, birbirlerine karşı saygı duyma, yapıcı ve yaratıcı davranma, eleştirel düşünme, hoşgörü ve açık fikirlilik özelliklerinin kazandırılması için her dersin içeriğine daha demokratik bir eğitim sistemi yansıtan çok kültürlü eğitim anlayışı dahil edilebilir. Bu kapsamda ders programlarının hazırlanmasında çok kültürlülük kavramının bir alt disiplin olarak her ders programının içerisine yerleştirilmesi gibi çok kültürlülük kavramının uygulanmasına yönelik somut adımlar atılabilir. Ayrıca bu araştırma, eğitim fakültesi mezunları ile diğer fakültelerden mezun olup öğretmenlik niteliğine sahip olmak isteyen adayların çok kültürlülüğge yönelik tutumlarının ölçülerek karşılaştırılma yapılabileceği, çok kültürlü tutuma yönelik fikirlerinin alınabileceği nicel ve nitel araştırmalarla geliştirilebilir. 


\section{Kaynakça}

Açıkalın, M. (2010). New approaches for teaching social studies: multicultural and global education. Elementary Education Online, 9 (3), 1226-1237.

APA. (2002). Guidelines on multicultural education, training, research, practice, and organizational change for psychologists. Erişim tarihi: 26 Aralı 2012. http://www.apa.org/pi/multiculturalguidelines/homepage.html

Banks, J. A. (1993). Approaches to multicultural curriculum reform. Içinde J. Banks ve C. Banks (Ed.). Multicultural education: Issues and perspectives. Boston: Allyn \& Bacon.

Banks, J. A., Cookson, P., Gay, G., Hawley, W. D., Irvine, J. J., Nieto, S., et al. (2001). Diversity within unity: Essential principles for teaching and learning in a multicultural society. http://www.educ.washington.edu/coetestwebsite/pdf/DiversityUnity. pdf adresinden 27 Aralık 2012 tarihinde alınmıştır.

Banks, J.A. ve Banks, C. A. M. (2009). Multicultural education: Issues and perspectives ( $7^{\text {th }}$ ed.). Hoboken, NJ: John Wiley \& Sons (p. 1).

Başbay, A. ve Bektaş, Y. (2009). Çok kültürlülük bağlamında öğretim ortamı ve öğretmen yeterlikleri. Eğitim ve Bilim, 34, 30-43.

Başbay, A. ve Kağnıcı, D. (2011). Çok kültürlü yeterlik algıları ölçeği: Bir ölçek geliştirme çalışması. Eğitim ve Bilim, 36 (161), 199-212.

Capella-Santana, N. (2003). Voices of teacher candidates: Positive changes in multicultural attitu des and knowledge. Journal of Educational Research, 96, $182-190$

Chan, K. C. (2002). The visible and invisible in cross-cultural movement experiences: bringing in our bodies to multicultural teacher education. Intercultural Education, 13 (3), 245-257.

Cochran-Smith, M. (2002). Reporting on teacher quality: The politics of politics. Journal of Teacher Education, 53 (5), 379-382.

Çelik, T. (2011). Sosyal bilgiler öğretmen adaylarının çok kültürlü bakış açısı geliştirmelerinde medya okuryazarlğ̆l dersinin rolüne ilişkin bir çalışma. (Yayımlanmamış yüksek lisans tezi). Pamukkale Üniversitesi, Sosyal Bilimler Enstitüsü. 
Pedagojik Formasyon Öğrencilerinin Çok Kültürlü Eğitime Yönelik Tutumlarının Bazı Değişkenlere Göre İncelenmesi

Cırık, İ. (2008). Çok kültürlü eğitim ve yansımaları. Hacettepe Üniversitesi Ĕ̆itim Fakültesi Dergisi, 34, 27-40.

Cogan, J. J. ve Pederson, P. V. (2001). The development of civic values: Case study of the United States of America. International Journal of Educational Research, 35, 61-76.

D'Andrea, M. (2000). Postmodernism, constructivism and multiculturalism: Three forces reshaping and expanding our thoughts about counseling. Journal of Mental Health Counseling, 22 (1), 1-17.

Demir, S. (2012). Çok kültürlü eğitimin Erciyes Üniversitesi öğretim elemanları için önem derecesi. International Periodical for the Languages, Literature and History of Turkish or Turkic, 7 (4), 1453-1475.

Demir, S. ve Başarır, F. (2013). Çok kültürlü eğitim çerçevesinde öğretmen adaylarının öz-yeterlik algılarının incelenmesi. International Journal of Social Science, 6 (1), 609-641.

Ertürk, S. (1998). Eğitimde program geliştirme. Ankara: Meteksan.

Gasbarro, S. L. ve Matthews, D. (1994). New teachers' perceptions of the meaning of the term 'multiculturalism' in preservice education. Paper presented at the annual meeting of the American Educational Research Association, LA: New Orleans.

Gay, G. (1994). A Synthesis of Scholarship in Multicultural Education. NCREL's Urban Education Program, republished on the website by North Central Regional Educational Laborator - a subsidiary of Learning Point Associates. Erişim tarihi: $\quad 14 \quad$ Ocak 2013 http://www.ncrel.org/sdrs/areas/issues/educatrs/leadrshp/le0sy.htm

Gay, G. (1995). Curriculum Theory and Multicultural Education. In J.A. Banks and C.A. McGee Banks (Eds.). Handbook of Research on Multicultural Education. (p. 25-43). NY: Simon and Schuster Macmillan.

Grant, C. ve Koskela, R. (1986). Education that is multicultural and the relationship between preservice campus learning and field experiences. The Journal Of Educational Research, 79 (4), 197-204.

Grant, C. ve Sleeter, C. (1998). Turning on learning: Five approaches to multicultural teaching plans for race, class, gender, and disability. Upper Saddle River, NJ: Prentice-Hall. 
Hasırc1, Ö. K. ve Gözük, Ö. (2012). Sinıf öğretmenlerinin çok kültürlülük tutumları ile düşünme stilleri arasındaki ilişki. 2. Ulusal Eğitim Programları ve Öğretim Kongresi, Bolu.

Highlen, P. (1996). MCT theory and implications for organizations/systems. Içinde D. W. Sue, A.E. Ivey, P.B. Pedersen (Ed.). A Theory of Multicultural Counseling \& Therapy (p. 65-85). California: Brooks/Cole Publishing Company.

House, R J., Hanges, P.J., Javidan, M., Dorfman, P.W., ve Gupta, V. (2004). Culture, leadership and organizations: The GLOBE study of 62 Societies. Sage Publications Inc.

Karasar, N. (1998). Bilimsel araştırma yöntemi. Ankara: Nobel Yayın Dağıtım.

Keller, C. (2001). Effect of teachers' stereotyping on students' stereotyping of mathematics as a male domain. The Journal of Social Psychology, 141 (2), 165-173.

McNeal, K. (2005). The influence of a multicultural teacher education program on teachers'

multicultural practices. Intercultural Education, 16 (4), 405-419.

MEB (2005). İlköğretim Fen ve Teknoloji Dersi (4-5.Sınıflar) Öğretim Programı. Ankara: MEB Talim ve Terbiye Kurulu Başkanlı̆̆ı. Temel eğitim programı: 1. Türkçe eğitimi 2. Din kültürü ve ahlak bilgisi. Ankara.

MEB (2008). Öğretmen yeterlilikleri: Öğretmenlik mesleği genel ve özel alan yeterlikleri. Ankara: Öğretmen Yetiştirme ve Eğitimi Genel Müdürlüğü. Erişim tarihi: 18 Şubat 2013. http://otmg.meb.gov.tr/YetGenel.html, http://otmg.meb.gov.tr/YetOzel.html ve http://otmg.meb.gov.tr/Otmg.html

MEB (2012). Öğretmen yeterlilikleri. Erişim tarihi: 18 Şubat 2013. http://otmg.meb.gov.tr

Neuharth-Pritchett, S., Reiff, J. C., ve Pearson, C. A. (2001). Through the eyes of preservice teachers: Implications for the multicultural. Journal of Research in Childhood Education, 15 (2), 256-269. Erişim tarihi: 28 Şubat 2013. http://www.freepatentsonline.com/article/Journal-Research-in 
Pedagojik Formasyon Öğrencilerinin Çok Kültürlü Eğitime Yönelik Tutumlarının Bazı Değişkenlere Göre İncelenmesi

Ngai, P.B. (2004). A Reinforcing curriculum and program reform proposal for 21st century teacher education: Vital first steps for advancing K-12 multicultural education. Equity \& Excellence in Education, 37 (4), 321-331.

Özdemir, M. ve Dil, K. (2013). Öğretmenlerin çok kültürlü eğitime yönelik tutumları: Çankırı ili örneği. Ankara Üniversitesi Eğitim Fakültesi Dergisi, 46 (2), 215-232.

Parekh, B. (1986). The Concept of Multi-Cultural Education. Içinde S.Mogdil, G. Verma, K. Mallick ve C. Mogdil (Ed.). Multicultural Education, The Interminable Debate. (p. 27). Falmer Press, Lewes and Philadelphia.

Parekh, B. (2000). Rethinking multiculturalism: Cultural diversity and political theory. Cambridge, MA: Harvard University Press.

Peterson, P.B. (1991). Multiculturalism as a generic approach to counseling. Journal of Counseling and Development, 70, 6-12.

Polat, S. (2009). Öğretmen adaylarının çok kültürlü eğitime yönelik kişilik özellikleri, International Online Journal of Educational Sciences. 1 (1), 154164.

Polat, S. (2012). Okul müdürlerinin çok kültürlülüğe ilişkin tutumları. Hacettepe üniversitesi Eğitim Fakültesi Dergisi, 42, 334-343.

Professional standards for the accreditation of teacher preparation institutions, (2008). Experiences workingwith diverse students. Erişim tarihi: 10 Ocak 2013. http://www.ncate.org

Sheets, R. H. \& Chew, L. (2000). Preparing Chinese American teacher: Implications for multicultural education. Annual Meeting of the American Educational Research Association. ERIC Digest ED 446039.

Siviş, R. (2002). Yapılandırmacı yaklaşım ve Türkiye'de psikolojik danışma alanındaki uygulanabilirliği. Türk Psikolojik Danışma ve Rehberlik Dergisi, $17(2), 43-48$.

Smith, R. (1998). Challenging privilege: white male middle-class opposition in the multicultural education terrain. Içinde R. Cha'vez Cha'vez, ve J. O'Donnell (Ed.). Speaking The Unpleasant: The Politics of (Non) Engagement in The Multicultural Education Terrain.. (p. 197-210). Albany, NY: State University of New York Press. 
Spiecker, B. ve Steutel, J. (2001). Multiculturalism, pillarization and liberal civic education in the Netherlands. International Journal of Educational Research, $35,293-304$.

Valentiin, S. (2006). Addressing diversity in teacher education programs. Education, 127 (2), 196-202.

Yavuz, G. ve Anıl, D. (2010). Öğretmen adayları için çok kültürlü eğitime yönelik tutum ölçeği: Güvenirlik ve geçerlik çalışması. International Conference on New Trends in Education and Their Implications. Türkiye: Antalya.

Yazıcı, S., Başol, G. ve Toprak, G. (2009). Öğretmenlerin çok kültürlü eğitim tutumları: Bir güvenirlik ve geçerlik çalışması. Hacettepe Üniversitesi Eğitim Fakültesi Dergisi, 37, 229-242.

Yükseköğretim Kurulu [YÖK]. (2009). 08 Eylül 2009 tarih ve 28565 Sayılı yazısı.

Yükseköğretim Kurulu (YÖK). (2010). 28.01.2010 tarih ve 03317 Sayılı yazısı. 